\title{
A comparison of anti-cancer activity against the prostate cancer cell line and antioxidant activity of different honey
}

\author{
J. Somaru, S. Sivaraja and M. Chopra \\ IBBS, School of Pharmacy and Biomedical Sciences, University of Portsmouth, Portsmouth PO12DT, UK
}

Inflammation and oxidant induced damage are believed to play an important role in the pathology of cancer. Honey is well known for its anti-inflammatory and antioxidant activity. In our previous study we demonstrated in vitro anti-proliferative activity of honey against the Caco2 (colon cancer cell line) cells ${ }^{1}$ and showed that the effects can vary between the different varieties of honey.

In the present study we have examined anti-proliferative activity of a $10 \%$ solution of different varieties of honey against the PC3 cell line (established human prostate aggressive cancer cell line) and compared the effects with the antioxidant and phenolic content of the honey. Anti-proliferative effects were examined using the MTT assay. Antioxidant activity was determined with the FRAP assay and phenolic content using the Folin Ciocalteu method.

Since honey contains $30 \%$ glucose and $40 \%$ fructose sugars, therefore an equivalent concentration expected in a $10 \%$ solution of honey i.e 3\%glucose plus 4\% fructose were also tested for their anti-proliferative effects on the PC3 cell line.

Results are shown in the table below:

\begin{tabular}{|c|c|c|c|}
\hline & $\begin{array}{l}\% \text { Cell viability } \\
\text { Mean (SEM) }\end{array}$ & $\begin{array}{l}\text { FRAP assay Ferrous ions } \\
\text { produced by the antioxidants in } \\
\text { the honey } \mu \text { mol/LMean (SEM) }\end{array}$ & $\begin{array}{l}\text { Phenolic content } \mu \text { g gallic } \\
\text { acid equivalent } \\
\text { Mean (SEM) }\end{array}$ \\
\hline *PBS control & $97(1.8)$ & - & - \\
\hline $3 \%$ Glucose $+4 \%$ Fructose & $45 \cdot 5(1 \cdot 5)$ & - & - \\
\hline Rowse Commercial honey & ${ }^{\mathrm{a}} 44.2(0.8)$ & a $598(6 \cdot 3)$ & a $54 \cdot 3(0 \cdot 2)$ \\
\hline Asda honey & $* \mathrm{~b}_{56} 4(2.8)$ & $b_{576}(5 \cdot 9)$ & $b_{41} .5(0.4)$ \\
\hline Tesco honey & $* \mathrm{c}_{40} \cdot 8(0 \cdot 9)$ & $c_{313(3 \cdot 7)}$ & ${ }^{c} 28.9(0.5)$ \\
\hline Manuka $5^{+}$honey & *b $57.9(0.7)$ & $\mathrm{d}_{956}(12 \cdot 1)$ & $\mathrm{d}_{72} \cdot 4(0 \cdot 3)$ \\
\hline Pure Raw honey & ${ }^{a} 47.4(1.45)$ & $\mathrm{d}_{1215(8.8)}$ & $\mathrm{d}_{73.7(0.2)}$ \\
\hline
\end{tabular}

* Stock solutions of honey and glucose plus fructose were prepared in sterile PBS.

Percentage of viable cells in the MTT assay were calculated relative to the cells grown in a control media where the absorbance values in the presence of unsupplemented media were normalised to $100 \%$. Significance of difference was measured using the Independent t-test. *denotes significant difference in cell viability in the presence of honey at $P<0.01$ compared to that observed in the presence of $3 \%$ glucose and $4 \%$ fructose. Significance of differences among the honey is shown as superscripts a-c. Those not sharing the same superscript within a column are significantly different at $P<0.05$.

Significant differences were observed between the antioxidant activity and phenolic content of different honey and there was a positive correlation between the phenolic content and antioxidant activity displayed by the honey $(\mathrm{r}=0.944, P<=0.001$, Pearson correlation). Our study showed that incubation of PC3 cancer cell line for 15 hour with $10 \%$ honey resulted in reduction of the cell viability. Since glucose plus fructose supplementation of the media showed an effect similar to that exerted by the various honey, it suggests that the reduction in cell viability seen with the honey is likely to be due to the osmolarity changes of cells in the presence of sugars in the media. No correlation was observed between the cell viability and antioxidant activity and phenolic content of the honey

In summary, antioxidant and phenolic content of honey varies between honey and the anti-proliferative effects of honey in an in vitro assay with prostate cancer cell line is likely to be due to their sugar and not the antioxidant and/or phenolic content.

1. Chai J, Chopra M. Proc Nutr Soc 72, E259, 2013. 